\title{
Maturity and Regional Influences on Watercore Development and its Postharvest Disappearance in 'Fuji' Apples
}

\author{
F. Roger Harker ${ }^{1}$ and Christopher B. Watkins ${ }^{2}$ \\ The Horticulture and Food Research Institute of New Zealand, Mt. Albert Research Centre, Private Bag \\ 92 169, Auckland, New Zealand \\ Paul L. Brookfield \\ The Horticulture and Food Research Institute of New Zealand, Hawke's Bay Research Centre, Private \\ Bag 1401, Havelock North, New Zealand
}
Mellisa J. Miller, Suzanne Reid, Phillippa J. Jackson, Roderick L. Bieleski, and Tim Bartley
The Horticulture and Food Research Institute of New Zealand, Mt. Albert Research Centre, Private Bag 92 169, Auckland, New Zealand

\begin{abstract}
AdDITIONAL INDEX words. Malus $\times$ domestica, fruit volume, air space, density
Abstract. Preharvest development and postharvest disappearance of watercore in 'Fuji' apples (Malus $\times$ domestica Borkh.) from a northern (Hawke's Bay, latitude $39^{\circ}$ south) and southern (Otago, latitude $45^{\circ}$ south) region of New Zealand were compared. A new method for quantifying watercore was developed. A photocopy was taken of the symptoms after each fruit was cut in half through the equator, and then the area of affected flesh (photocopies black) was measured using morphometric methods and compared to the area of unaffected flesh (photocopies white). Watercore was more severe and developed earlier in the season in Otago than in Hawke's Bay. In Otago, a block-type watercore predominated, disorder symptoms initially appearing in the tissues located at the junction of two carpels, while in Hawke's Bay a radial-type of watercore predominated, initially appearing in the tissues surrounding the coreline vascular bundles. Regression analysis identified that orchard and harvest date accounted for most of the differences in watercore symptoms and that the initial appearance of low levels of watercore was the best predictor that fruit would start to develop commercially significant levels of watercore. Incorporation of background color, internal ethylene concentration, starch pattern index, and firmness only slightly improved the regression coefficient. Watercore disappeared from the flesh during storage of fruit from both regions. Fruit from early harvests had the least severe symptoms, and the highest rates of watercore disappearance during storage. In fruit with more severe symptoms at harvest, its disappearance during storage was associated with an increase in fruit volume and air space, which occurred despite continuing mass loss. We suggest that during storage, the extracellular fluid associated with watercore symptoms is absorbed into the cells, and thus drives the increase in fruit volume.
\end{abstract}

Production of 'Fuji' apples has rapidly increased worldwide (O'Rourke, 1994), and it is now an important cultivar internationally. However, as fruit production has increased, a number of potentially serious fruit quality defects have become apparent. The most important of these is watercore; 'Fuji' fruit harvested at the optimum color and starch for market requirements are likely to have watercore at harvest (Watkins et al., 1993). In many apple cultivars, especially 'Delicious', the development of watercore is damaging, since the tissue becomes anaerobic and subsequently breaks down during storage (Marlow and Loescher, 1984). 'Fuji' fruit, however, appear to tolerate high levels of watercore without developing internal disorders during storage (O'Loughlin and Graham, 1993; Watkins et al., 1993), and coreline and inner core browning only occurs in severely affected fruit (Fukuda, 1984).

Received for publication 17 June 1998. Accepted for publication 3 Dec. 1998. We thank ENZA (New Zealand) International and the New Zealand Foundation for Research Science and Technology for funding this study; Ian Hallett for his advice on morphometric methodology; Sarah Laing for preparing Fig.1; Warwick Henshall for his advice on climate data; and the pilots and staff of Southflight Aviation Ltd. for the safe flights and smooth landings in their Piper Aztec. The cost of publishing this paper was defrayed in part by the payment of page charges. Under postal regulations, this paper therefore must be hereby marked advertisement solely to indicate this fact.

${ }^{1}$ To whom reprint requests should be addressed; e-mail rharker@hort.cri.nz. ${ }^{2}$ Current address: Department of Fruit and Vegetable Science, Cornell University, Ithaca, NY 14853
Watercore is identified as a defect and fruit containing watercore are downgraded according to international grade standards for class 1 (Organisation for Economic Co-operation and Development, 1983). However, Fuji was selected by Japanese breeders for its high watercore levels, since watercore is desired by Japanese consumers. Watercore is no longer considered a defect in U.S.grown 'Fuji'.

Given the possible impact of watercore on fruit quality, it became important to identify factors that may influence watercore incidence in New Zealand-grown 'Fuji'. A wide range of environmental and physiological factors have been implicated in the development of this disorder (see review by Marlow and Loescher, 1984). Of these, the influence of fruit maturity was identified as critical, since watercore incidence and severity in 'Fuji' is associated with harvest date and fruit maturity (Bowen and Watkins, 1997; Watkins et al., 1993). However, industry reported that watercore developed earlier and with greater severity in southern or colder regions of New Zealand suggesting that climatic as well as maturity factors were involved. In this study we compared the relationship between harvest maturity and watercore for a northern (Hawke's Bay) and southern (Otago) region, to determine the relative influences of region and maturity on watercore development. In addition, we examined the relationship between watercore severity at harvest, and its amelioration during storage at $0^{\circ} \mathrm{C}$, and describe some of the physical changes that occur as a result of this process. 
Table 1. Harvest dates and fruit mass categories for 'Fuji' apples used in watercore studies in 1993 and 1994.

\begin{tabular}{|c|c|c|c|c|c|}
\hline \multirow[b]{2}{*}{ Year } & \multirow[b]{2}{*}{ Harvest } & \multicolumn{2}{|c|}{ Otago } & \multicolumn{2}{|c|}{ Hawke's Bay } \\
\hline & & Date & $\begin{array}{c}\text { Fruit } \\
\text { mass } \\
\text { class }(\mathrm{g})\end{array}$ & Date & $\begin{array}{c}\text { Frui } \\
\text { mass } \\
\text { class }(g)\end{array}$ \\
\hline \multirow[t]{6}{*}{$\overline{1993}$} & 1 & 18 March & 150 & --- & --- \\
\hline & 2 & 25 March & 150 & --- & --- \\
\hline & 3 (Early) & 1 April & 186 & 29 March & 186 \\
\hline & 4 & 7 April & 186 & --- & --- \\
\hline & 5 (Middle) & 15 April & 186 & 13 April & 186 \\
\hline & 6 (Late) & 29 April & 186 & 26 April & 186 \\
\hline \multirow[t]{3}{*}{1994} & Early & 7 April & 186 & 30 March & 186 \\
\hline & Middle & 21 April & 186 & 14 April & 186 \\
\hline & Late & 5 May & 186 & 28 April & 186 \\
\hline
\end{tabular}

\section{Materials and Methods}

Plant material. 'Fuji' apples were harvested from eight orchards-four in the Hawke's Bay region (latitude $39^{\circ}$ South) and four in the Otago region (latitude $45^{\circ}$ South). At each harvest date, two trees from each orchard were stripped of fruit. Otago-grown samples were harvested at weekly intervals during 1993, and at an early, middle, and late period of the commercial picking season in 1994 (Table 1). Hawke's Bay-grown fruit were taken at early, middle, and late periods of the commercial picking season in both years (Table 1).

The fruit from each two-tree replication were graded by mass before being sorted into different maturity categories. At each sample date, fruit from the most common mass class were taken for further study (Table 1). This was done to avoid potential bias associated with selecting fruit of a single mass class throughout the experiment. Fruit size increases slowly on the tree throughout the picking season, so if a single mass class were used, fruit selected in the first harvest would be likely to contain early maturing apples from exposed outer branches (and thus larger than the population mean), while fruit selected in the last harvest might be late maturing apples harvested from the inner shaded parts of the tree (and thus be smaller than the population mean). Fruit in the study sample were then sorted into different maturity categories using a background color chart, where 1 was the greenest and 7 was the yellowest. Up to 30 apples of color categories $<1,1,2,3$, and 4 were collected from each two-tree replicate for use in subsequent studies (very few fruit were yellower than 4 at any harvest date). The same group of four people at each harvest undertook color grading, in order to reduce variability in the subjectivity of the grading. Each fruit was identified by background color, tree, orchard, harvest date and region, packed in commercial cartons and then transported to Auckland, where 10 fruit (from each category) were assessed for maturity on the day following harvest, and the remainder placed in storage at 0 ${ }^{\circ} \mathrm{C}$. Samples of fruit were removed from storage after 6 and 12 weeks and quality of the fruit assessed after holding the fruit for $1 \mathrm{~d}$ at $20^{\circ} \mathrm{C}$.

Fruit MATURITY AND QUALITY ASSESSMENTS. Internal ethylene concentration (IEC) was determined by gas chromatography using $1 \mathrm{~mL}$ samples of gas collected from the core cavity. Background color had already been determined during collection of fruit samples, but in addition, was measured using a Minolta CR-300 Chroma Meter (Minolta Camera Co., Osaka, Japan) to determine Commission International d'Eclairage (CIE) L* $\mathrm{a}^{*} \mathrm{~b} *$ color space coordinates, which were converted to hue angle and chroma as described by McGuire (1992). The firmness of opposite sides of each fruit was measured using an EPT-1 Firmness tester (Lake City Technical Products Inc., Lake City, Canada) fitted with an 11.1-mm-diameter probe (Harker et al., 1996). The combined juice expressed from both sides of the fruit during firmness measurements was collected directly onto a hand-held refractometer ( $0 \%$ to $20 \%$ Atago, Tokyo, Japan) and soluble solids determined. Finally, each fruit was cut through the equator. The calyx end was reserved for watercore assessment, and the stem end dipped in a starch-iodine solution, before being assessed for starch hydrolysis on a scale from 0 (100\% staining) to $6(0 \%$ staining).

WATERCore ASSESSMENT. The calyx half of each fruit was

Fig. 1. Photographs show the sequential development of watercore symptoms. Radial watercore predominates in Hawke's Bay while block watercore predominates in Otago.
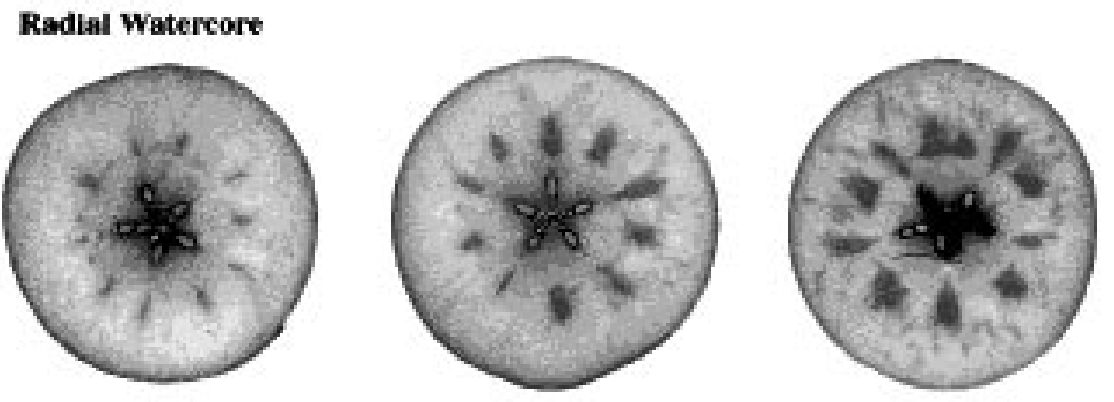

Block Watercore
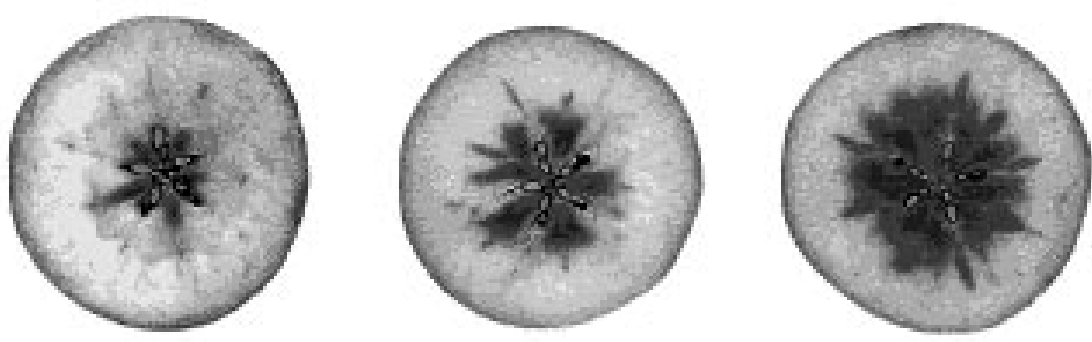

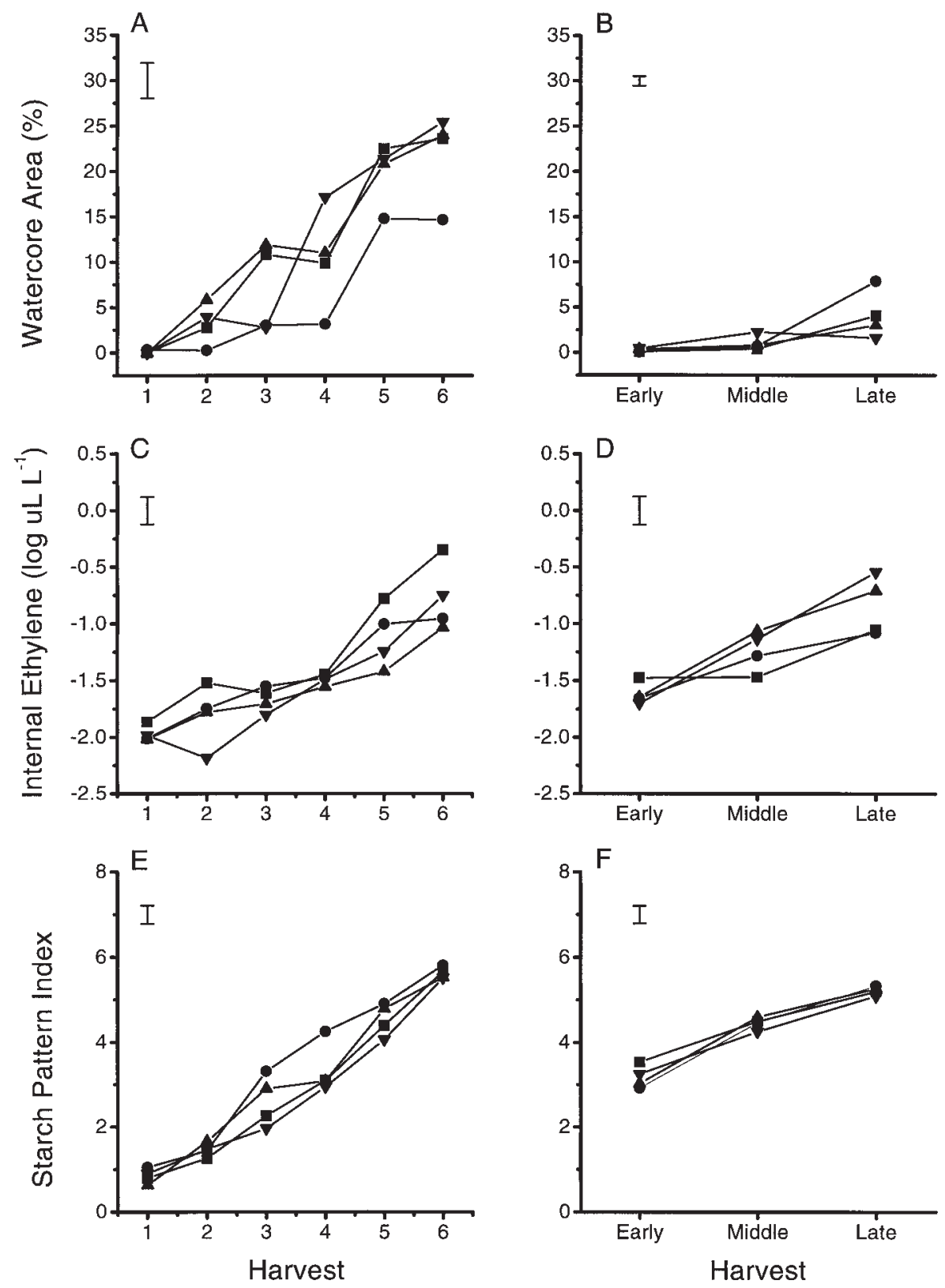

teorological data was accessed through the NIWA climate database server (http// www.niwa.cri.nz). Daily minimum and maximum temperatures had been recorded at research orchards (Horticulture and Food Research Institute of New Zealand Ltd.) located close to the commercial orchards used in this study. The respective research orchards were located at Havelock North (Hawke's Bay) and Clyde (Otago).

Statistical analysis. The first stage of analysis examined watercore dependence on several measured variables using multiple regression analysis. Due to the observational nature of the data, it was not possible to determine cause and effect relationships. The fitted models, however, can be used for prediction, i.e., for given measured values of an independent variable (e.g., harvest date, IEC), a predicted value for watercore can be obtained.

In the second stage of the analysis, the proportion of fruit with watercore in each of several groups (defined by region, orchard, harvest date, and storage) were calculated and ANOVA carried out to determine if any of the factors or their interactions had a significant effect on either the proportion of fruit with watercore or the rate of loss of watercore. For these analyses, watercore was considered as being either present or absent from each fruit. The number of fruit with watercore was divided by the total number of fruit. This gave a proportion between 0 and 1 , and thus it was necessary to transform the data by taking log $(\mathrm{P} / 1-\mathrm{P})$, where $\mathrm{P}$ is the proportion of fruit with watercore. The rate at which watercore disappeared was calculated using the formula: Rate $=1-\mathrm{P}_{\mathrm{S}} / \mathrm{P}_{\mathrm{H}}$ where $\mathrm{P}_{\mathrm{H}}$ is the proportion of fruit with watercore at harvest and $\mathrm{P}_{\mathrm{S}}$ is the proportion of fruit with watercore after 6 or 12 weeks storage. A value of 0.4 suggests that $40 \%$ of the fruit with watercore at harvest had none after storage. Differences between means were tested using the Tukey LSD test at the 5\% level

Fig. 2. Development of watercore and associated changes in maturity in 'Fuji' apples grown in Otago (A, C, E) and Hawke's Bay (B, D, F) during the 1993 harvest season. Watercore was measured as the area of fluid-soaked tissue in equatorial slices ( $\mathbf{A}$ and $\mathbf{B})$, fruit maturity is indicated by internal ethylene concentrations ( $\mathbf{C}$ and $\mathbf{D})$ and starch pattern index (E and $\mathbf{F})$. Values represent means for individual orchards $(\boldsymbol{\square}, \boldsymbol{\nabla}, \boldsymbol{\nabla}, \mathbf{\Delta})$ and vertical lines indicate LSD (Fisher).

placed on a photocopier (Konica, model U-Bix 1017, Tokyo, Japan), and a photocopy taken of the freshly cut surface. The zone of fluid-soaked tissue showed up as a dark region on the photocopy, while the nonfluid-soaked tissue was white. This image was then analyzed using morphometric methods (Weibel, 1979). A grid was placed over the photocopied image, and the number of intercepts (crosses on the grid) which coincided with infiltrated tissue, as well as the number of intercepts which coincided with the fruit cross-section were counted. The number of intercepts in the region of watercore were presented as the percentage of the number of intercepts across the entire fruit cross-section. The cross-section of the fruit was defined by $\approx 65$ intercepts.

Temperatures DURING FRUIT Growth and Maturation. Me- of significance, with appropriate transformations to reduce variance.

Postharvest Changes In FRUIT Volume AND AIR SPACE. Hawke's Bay-grown apples from early, middle and late harvests (9 and 23 Apr. and 6 May 1992, respectively) were stored at $0{ }^{\circ} \mathrm{C}$ for up to 20 weeks. Fifty fruit from each harvest were individually identified, and at regular intervals throughout storage fruit mass and volume were measured, as follows. A beaker of water was placed on a balance and tared. Each apple was then placed into the beaker of water and its mass recorded. The apple was then submerged using a probe constructed from three fine needles, and the volume of displaced water was recorded. Measurements of fruit volume and mass were carried out in a $3{ }^{\circ} \mathrm{C}$ cold store using water at $0{ }^{\circ} \mathrm{C}$ to minimize warming of fruit during assessments. Each fruit was dried before being returned to cold storage. Concurrent with nondestructive measurements of fruit mass and volume, an additional 50 fruit were removed from cold storage and destructively assessed for watercore and juice specific gravity. Specific gravity was measured for juice extracted from plugs of outer cortical tissue 
Table 2. Comparisons of apple maturity and watercore levels in Otago and Hawke's Bay 'Fuji' during early, middle, and late periods of the 1993 commercial harvest. Values represent the means across all orchards for watercore (percent of cross-sectional area), log of internal ethylene concentration, and starch pattern index.

\begin{tabular}{|c|c|c|c|}
\hline \multirow[b]{2}{*}{ Harvest } & \multicolumn{2}{|c|}{ Region } & \multirow[b]{2}{*}{ LSD $_{\text {(Tukev) }}$} \\
\hline & Otago & Hawke's Bay & \\
\hline & \multicolumn{3}{|c|}{ Watercore (\% cross-sectional area) } \\
\hline Early & 7.1 & 0.2 & 7.6 \\
\hline Middle & 19.9 & 1.0 & \\
\hline \multirow[t]{2}{*}{ Late } & 21.9 & 4.2 & \\
\hline & \multicolumn{3}{|c|}{ Internal ethylene concentration $(\mathrm{Log})$} \\
\hline Early & -1.67 & -1.62 & 0.50 \\
\hline Middle & -1.11 & -1.24 & \\
\hline \multirow[t]{2}{*}{ Late } & -0.77 & -0.85 & \\
\hline & \multicolumn{3}{|c|}{ Starch pattern index } \\
\hline Early & 2.61 & 3.18 & 0.74 \\
\hline Middle & 4.54 & 4.45 & \\
\hline Late & 5.63 & 5.23 & \\
\hline
\end{tabular}

of five fruit. Juice was extracted using a garlic crusher, and specific gravity was determined from the weight (measured to $0.001 \mathrm{~g}$ precision) of 1-mL samples of juice collected into preweighed micropippette tips. Percent air space was estimated from the fruit density (D) (volume/mass) and the specific gravity (SG) of the juice as described by Hatfield and Knee (1988): Percent airspace $=1-\mathrm{D} / \mathrm{SG}$ juice.

\section{Results and Discussion}

REGIONAL DIFFERENCES IN WATERCORE SYMPTOMS. The predominant type of watercore was affected by growing region(Fig. 1). In Hawke's Bay-grown 'Fuji', the symptoms first appeared as fluid-soaking of tissues immediately adjacent to coreline vascular bundles. As the symptoms progressed, the area of fluid-soaking simultaneously expanded into both the core and cortex, as typical for radial watercore in many apple cultivars including 'Delicious' (Williams, 1966). In contrast, disorder symptoms in Otago-grown fruit first appeared in tissues located at the junction of two adjacent carpels. The area of fluid-soaking then expanded to the coreline, before progressing into the cortex until, in extreme cases, it reached the skin. The type of watercore symptoms that predominates in Otago is known as block watercore (Fig. 1). Each watercore type was generally associated with a specific growing region; however, a variable proportion of Otago-grown 'Fuji' contained radial watercore, and block watercore was occasionally seen in Hawke's Bay-grown fruit (data not presented).

EFFECT OF HARVEST DATE, MATURITY, AND ORCHARD FACTORS ON WATERCORE. Otagogrown fruit developed watercore earlier in the season than occurred in Hawke's Bay-grown fruit in 1993 and 1994. However, watercore appeared earlier in 1993 and the symptoms were generally more severe, and therefore most of the data presented here relate to the 1993 season.

The maturity of fruit advanced with successive harvest dates, as is indicated by increases in the starch pattern index and IEC (Fig. 2, Table 2). For Otago fruit, the inclusion of harvest date, orchard, and harvest date by orchard interactions, in multiple regression analysis explained $56 \%$ and $41 \%\left(R^{2}=0.56, p<0.001\right.$, and $R^{2}=$ $0.41, p<0.001)$ of the variation in watercore levels in 1993 and 1994, respectively. Inclusion of background color, IEC and starch pattern indices into the regression model improved the $R^{2}$ from $0.56(p<0.001)$ to $0.59(p<0.001)$ in 1993. In 1994, the inclusion of background color, chroma and hue of the green portion of fruit, chroma of red portion of the fruit, and flesh firmness, into the regression model improved the $R^{2}$ from $0.41(p<0.001)$ to $0.47(p$ $<0.001)$.

For Hawke's Bay fruit, the inclusion of harvest date, orchard, and harvest date by orchard interaction into the regression model

Fig. 3. Daily maximum and minimum temperatures in Otago (-) and Hawke's Bay (- - - ) for 1993 (A) and 1994 (B).

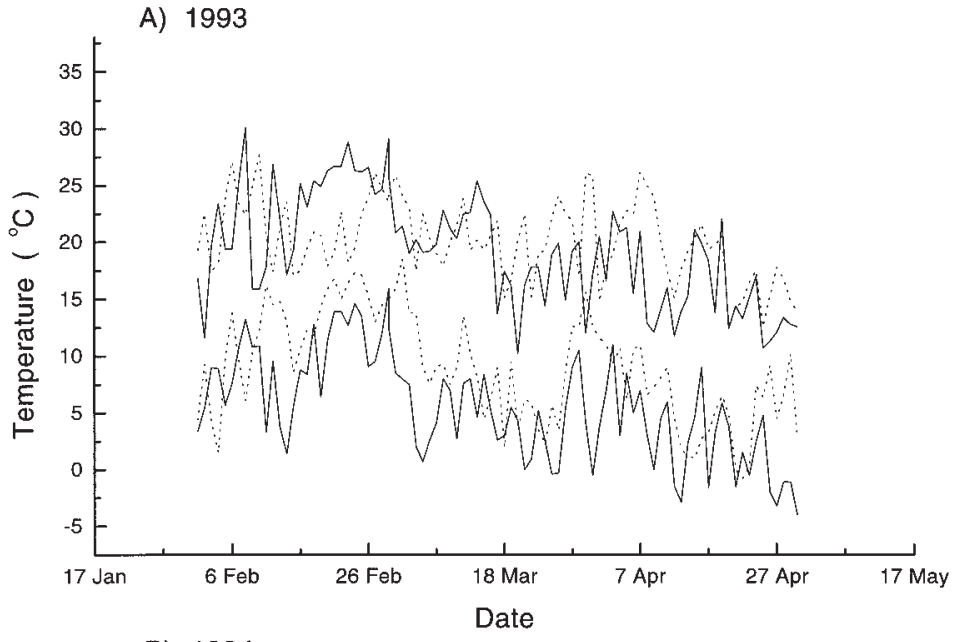

B) 1994

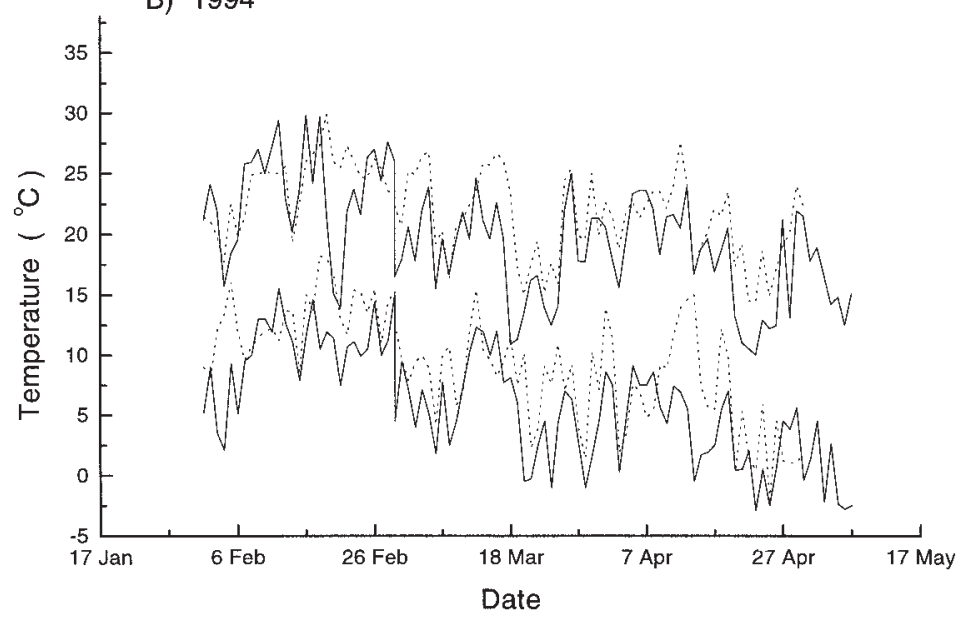



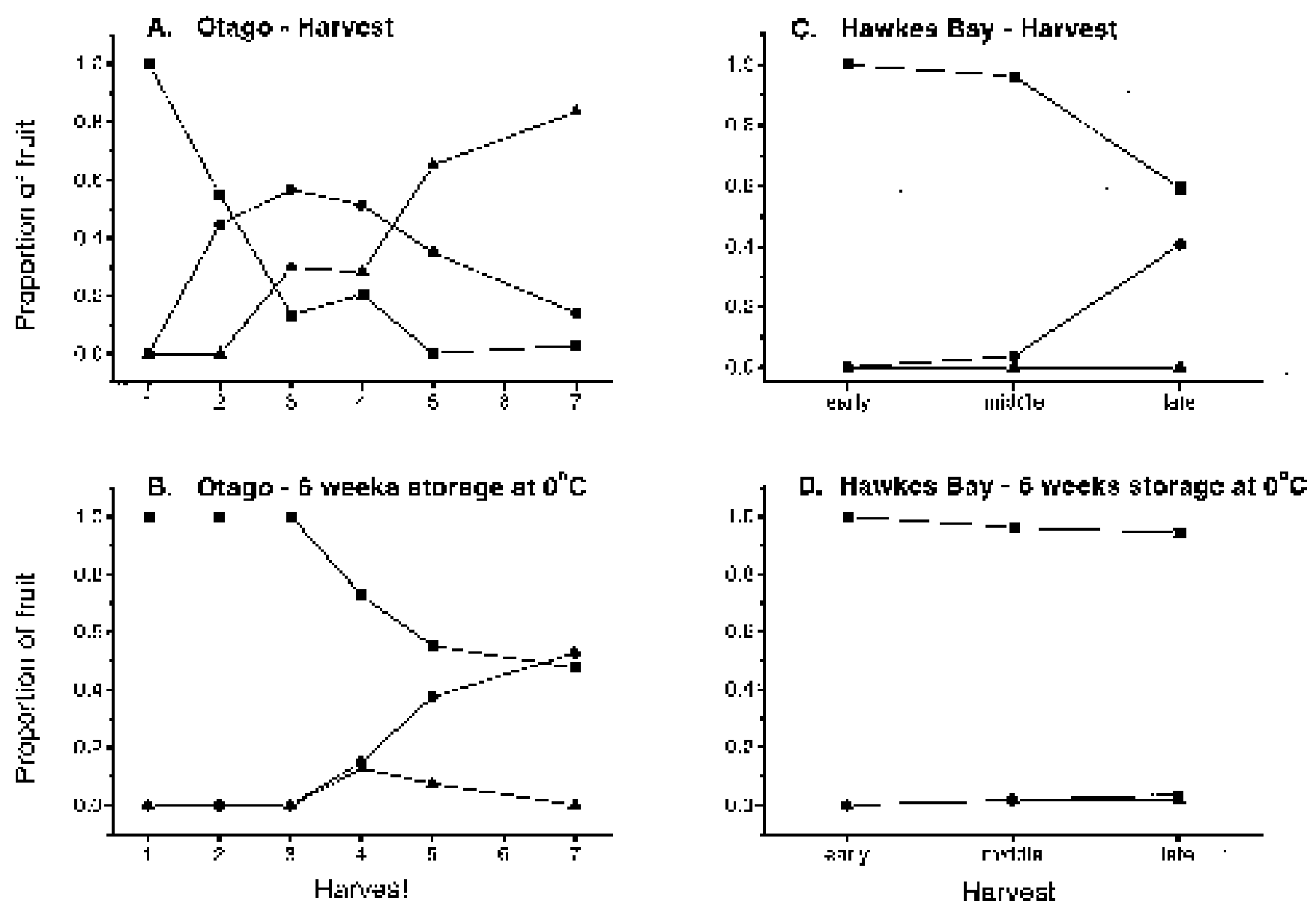

Fig. 4. The range of intensities of watercore symptoms found in 'Fuji' apples harvested from typical Otago and Hawke's Bay orchards during 1993 at different dates and after 6 weeks storage at $0{ }^{\circ} \mathrm{C}$. (A) Otago orchard at harvest; (B) Otago orchard after 6 weeks storage; (C) Hawke's Bay orchard at harvest; (D) Hawke's Bay orchard after 6 weeks storage. Values represent the proportion of fruit with specified symptoms, $<5 \%(\mathbf{\square}), 5$ to $15 \%(\bullet)$, and $>15 \%(\mathbf{\Delta})$ of cross-section of equatorial slices containing fluid-soaked tissues.

explained $42 \%$ and $25 \%$ of the variation in watercore levels in 1993 and 1994, respectively. In 1993, the inclusion of maturity factors did not significantly improve the prediction of watercore. However, in 1994, the inclusion of background color, IEC, soluble solids content, chroma of the green side of the fruit, and flesh firmness into the regression model improved the $R^{2}$ from 0.25 ( $p<$ $0.001)$ to $0.35(p<0.001)$.

For fruit from both regions, differences in watercore were mainly associated with harvest date and orchard (Fig. 2), but the inclusion of maturity parameters into the regression model, either did not, or only slightly, improved the $R^{2}$. Even when all parameters were included in the regression model, between $41 \%$ and $65 \%$ of the variability in watercore levels remained unaccounted for.

EFfect of Climate on watercore. It is often difficult to separate the influences of declining temperatures that occur toward the end of the season from the influences of advancing maturity, since both occur simultaneously. When fruit of similar maturity, according to maturity measurements such as starch pattern index and IEC, were compared from the two regions, Otago-grown fruit tended to have more severe watercore than Hawke's Bay-grown 'Fuji' (Table 2). This observation indicates that physiological maturity per se is not the major factor influencing watercore.

Air temperatures during fruit growth and maturation typically are colder in Otago than in Hawke's Bay (Fig. 3). The average daily maximum and minimum temperatures (mean $\pm \mathrm{SE}$ ) from 1 Apr. to 2 May 1993 were $16.7 \pm 0.7^{\circ} \mathrm{C}$ and $2.7 \pm 0.7^{\circ} \mathrm{C}$ in Otago and 18.4 $\pm 0.7^{\circ} \mathrm{C}$ and $5.9 \pm 0.7^{\circ} \mathrm{C}$ in Hawke's Bay. From 30 Mar. to 5 May 1994 , the mean maximum and minimum temperatures were 18.0 $\pm 0.7^{\circ} \mathrm{C}$ and $3.3 \pm 0.6{ }^{\circ} \mathrm{C}$, and $20.6 \pm 0.5^{\circ} \mathrm{C}$ and $6.4 \pm 0.8^{\circ} \mathrm{C}$ in

Table 3. Development of watercore in 'Fuji' apples during maturation on the tree and subsequent disappearance during storage. Values represent mean proportion of fruit with watercore, where $0=$ no fruit had watercore and $1=$ all fruit had watercore.

\begin{tabular}{|c|c|c|c|c|}
\hline \multirow[b]{2}{*}{ Region } & \multirow[b]{2}{*}{ Harvest } & \multicolumn{3}{|c|}{ Storage period (weeks) } \\
\hline & & 0 & 6 & 12 \\
\hline & 1993 & & & \\
\hline \multirow[t]{3}{*}{ Otago } & Early & 0.594 & 0.042 & 0.000 \\
\hline & Middle & 0.957 & 0.611 & 0.099 \\
\hline & Late & 0.798 & 0.748 & 0.493 \\
\hline \multirow[t]{4}{*}{ Hawke's Bay } & Early & 0.082 & 0.000 & 0.000 \\
\hline & Middle & 0.252 & 0.041 & 0.000 \\
\hline & Late & 0.621 & 0.370 & 0.054 \\
\hline & 1994 & \multicolumn{3}{|c|}{$\mathrm{LSD}_{\text {(Tukey) }}=0.416$} \\
\hline \multirow[t]{3}{*}{ Otago } & Early & 0.783 & 0.063 & 0.000 \\
\hline & Middle & 0.899 & 0.384 & 0.000 \\
\hline & Late & 0.973 & 0.613 & 0.083 \\
\hline \multirow[t]{4}{*}{ Hawke's Bay } & Early & 0.000 & 0.000 & 0.000 \\
\hline & Middle & 0.085 & 0.009 & 0.000 \\
\hline & Late & 0.456 & 0.303 & 0.059 \\
\hline & & \multicolumn{3}{|c|}{$\mathrm{LSD}_{\text {(Tukey) }}=0.280$} \\
\hline
\end{tabular}




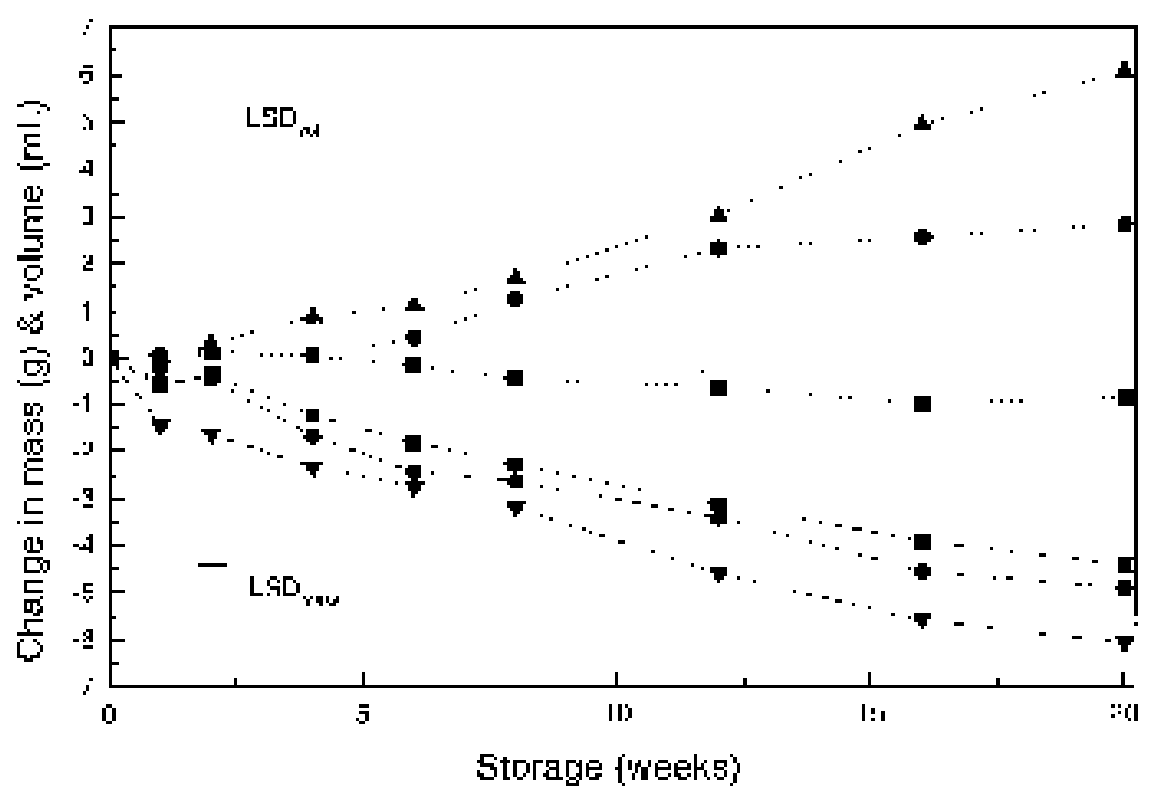

Fig. 5. Postharvest changes in mass (dashed) and volume (dotted) of Hawke's Baygrown 'Fuji' apples from early $(\mathbf{\square})$, middle $(\mathbf{O})$, and late harvests $(\mathbf{A})$. Points represent means for 50 fruit.

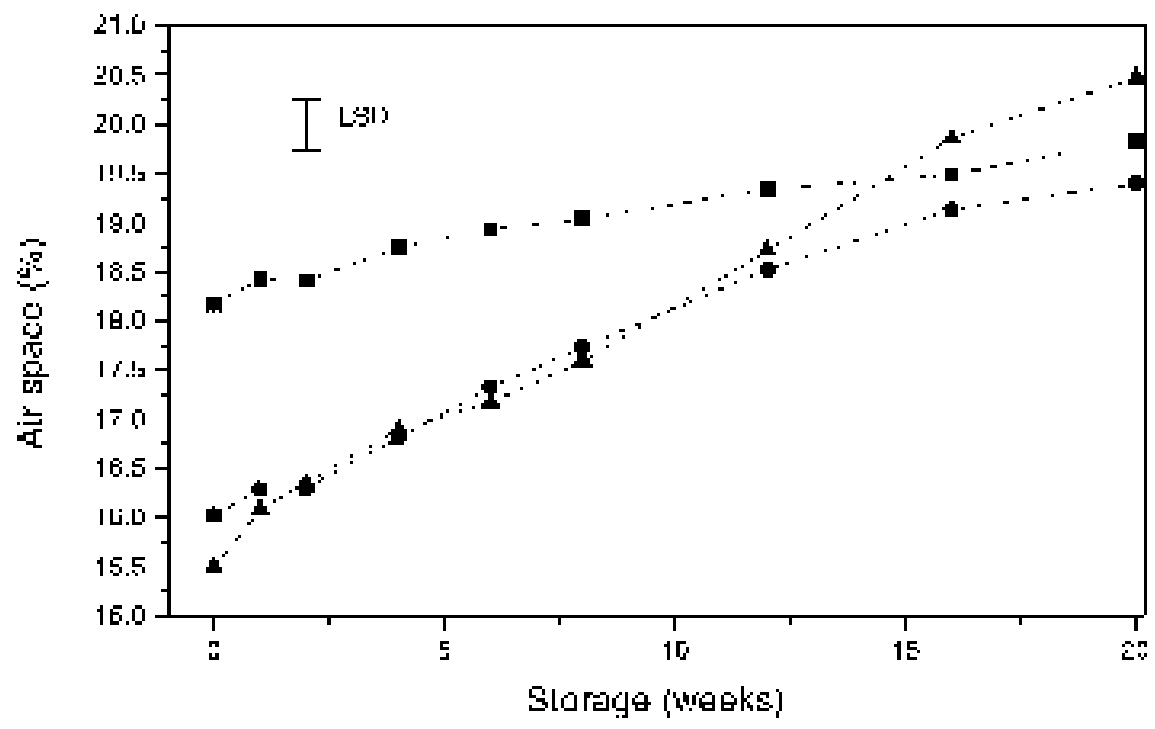

colder with daily minimum temperatures of $\approx 3$ ${ }^{\circ} \mathrm{C}$, and developed severe watercore. Overall temperatures were colder in 1993 than in 1994 (Fig. 3). Thus, the regional and seasonal differences in watercore probably relate to the different climates in Hawke's Bay and Otago. Bramlage and Watkins (1994) reached similar conclusions for superficial scald incidence in the two regions.

Watercore SEverity. From the time that watercore was first observed in the fruit, the severity of the symptoms increased as expressed as the precent of fluid-soaked tissue in equatorial sections. From a commercial perspective, it is the proportions of fruit that fall into different categories of severity of watercore which are most critical. In Fig. 4, the proportions of fruit with $<5 \%, 5 \%$ to $15 \%$, and $>15 \%$ of the equatorial slice being fluid-soaked, are shown for typical orchards from Otago and Hawke's Bay. In Otago, there is a gradual decline in the proportion of the crop containing little or no watercore $(<5 \%)$ with advancing harvest date. The proportion of the crop with moderate watercore (5\% to $15 \%$ ) increased during the first part of the season and then declined towards the end of the season. The proportion of the crop with severe watercore $(>15 \%)$ increased with advancing harvest date. The increases and decreases in the proportion of fruit with moderate watercore were respectively matched by decreases in the proportion of fruit with slight watercore in the early part of the season, and by increases in the proportion of fruit with severe watercore towards the end of the season (Fig. 4). In Hawke's Bay, moderate and severe watercore was only observed in fruit from the late harvest (Fig. 4).

DisAPPEARANCE OF WATERCORE DURING STORAGE. The proportion of fruit with watercore declined throughout the storage period, for both Otago- and Hawke's Bay-grown apples (Table 3). The time-course of events for disappearance of watercore in fruit with slight $(<5 \%)$, moderate $(5 \%$ to $15 \%)$, and severe $(>15 \%)$ symptoms, is shown for representative Otago and Hawke's Bay orchards in Fig. 4. Clearly, the proportions of fruit with different severi-

Fig. 6. Postharvest changes in air space of Hawke's Bay-grown 'Fuji' apples from early $(\mathbf{\square})$, middle $(\boldsymbol{O})$, and late harvests $(\boldsymbol{\Delta})$. Points represent means for 50 fruit.

Otago and Hawke's Bay, respectively. Studies in which the preharvest temperature of 'Fuji' fruit has been manipulated have demonstrated that temperature during maturation has a profound influence on watercore: slight to moderate watercore developed in fruit at $9{ }^{\circ} \mathrm{C}$, while only trace levels of watercore were detected at temperatures of 23 to $30^{\circ} \mathrm{C}$ (Yamada et al. 1994). Furthermore, when Yamada et al. (1994) imposed day/night temperature regimes on fruit, an $18 / 10^{\circ} \mathrm{C}$ regime resulted in development of trace to slight levels of watercore. Even though little watercore developed in the $18 / 10^{\circ} \mathrm{C}$ regime, the watercore rating was significantly higher than watercore ratings in fruit from $8 / 0{ }^{\circ} \mathrm{C}, 28 / 20{ }^{\circ} \mathrm{C}$ regimes or ambient temperatures. Temperatures in Hawke's Bay are were closest to the $18 / 10{ }^{\circ} \mathrm{C}$ regime used by Yamada et al. (1994) and developed little watercore. However, Otago was much ties of symptoms change dramatically as the watercore is reassimilated into the flesh. Attempts to separate the effects of harvest date, and the severity of symptoms at harvest on the rate at which watercore disappeared were unsuccessful. For example, the proportion of apples that had watercore at harvest but had no watercore after 6 weeks storage was 0.1 and 0.9 for late-harvested and early-harvested Otago-grown apples, respectively. This might be interpreted as showing that watercore disappeared at a higher rate in early-harvested fruit. However, early harvested fruit also generally have a lower incidence and less severe symptoms of watercore than late-harvested fruit. Thus these statistical rates of watercore loss reflect the initial watercore levels at harvest, rather than the physiological processes involved in its disappearance during storage.

An attempt to characterize the physical changes occurring in the flesh during storage of fruit with watercore was undertaken in a separate experiment. Fruit mass and volume changes, and associated 
calculations of \% air space, were characterized for early-, mid-, and late-harvested Hawke's Bay apples during storage (respective harvest watercore incidences of $2 \%, 4 \%$, and $4 \%$ of equatorial area fluidsoaked) (Figs. 5 and 6). Mass loss was similar for early-, mid- and late-harvested apples (Fig. 5). However, fruit volume increased at a higher rate in apples from late than from middle harvests, and fruit volume declined slightly in apples from early harvests (Fig. 5). The percentage air space in early-harvested fruit increased from $\approx 18 \%$ to $19.5 \%$ over a 20 -week period (Fig. 6), and in apples from middle and late harvests was much lower at harvest, $16 \%$ and $15.5 \%$ respectively, reflecting the increased fluid-soaking of the flesh. During storage, air space volume in fruit from middle and late harvests rapidly increased (Fig. 6). Around weeks 12 to 16, the air space volume in mid- and late-harvested apples approached or intercepted plots of air space in early harvested fruit (Fig. 6). Around this period, symptoms of watercore disappeared from the fruit (data not shown). Such changes in fruit mass, volume and airspace suggest that during storage, the extracellular fluid is absorbed into cells, which subsequently increase in volume, and thus drive an increase in fruit volume. We speculate that this reabsorption is the dominating factor in reassimilation of watercore, since mass loss was similar in fruit from all harvests.

\section{Conclusion}

The temporal development of watercore, the morphology and severity of symptoms all differed greatly between regions. Multiple regression analysis indicated that for individual regions, harvest date, orchard, and harvest date by orchard interactions were able to predict up to $59 \%$ of the variability in watercore values. Incorporation of maturity factors into the regression model provided little additional advantage. This suggests that the growing environment and climate may account for many of the differences in watercore between regions. Indeed, Otago was much colder than Hawke's Bay in the 1993 and 1994 seasons (Fig. 3). Even so, considerable variations in watercore levels exist between fruit harvested from the same tree or (in this study) each pair of trees (e.g., Fig. 4a, harvest 3). These differences in watercore may relate to different microclimates that exist within the tree, or other factors associated with different locations within the architecture of the tree. From a commercial perspective, prediction of watercore clearly needs to be undertaken at the orchard level, and initial appearance of low levels of watercore is the best predictor that fruit in a particular orchard will soon start to develop commercially significant levels of watercore.

\section{Literature Cited}

Bowen, J.H. and C.B Watkins. 1997. Fruit maturity, carbohydrate and mineral content relationships with watercore in 'Fuji' apples. Postharvest Biol.Technol. 11:31-38.

Bramlage, W.J. and C.B. Watkins. 1994. Influences of preharvest temperature and harvest maturity on susceptibility of New Zealand and North American apples to superficial scald. N.Z. J. Crop Hort. Sci. 22:69-79.

Fukuda, H. 1984. Relationship of watercore and calcium to the incidence of internal storage disorders of 'Fuji' apple fruit. J. Jpn. Soc. Hort. Sci. 53:298-302.

Harker, F.R., J.H. Maindonald, and P.J. Jackson. 1996. Penetrometer measurement of apple and kiwifruit firmness: Operator and instrument differences. J. Amer. Soc. Hort. Sci. 121:927-936.

Hatfield, S.G.S. and M. Knee. 1988: Effects of water loss on apples in storage. Int. J. Food Sci. Technol. 23:575-585.

Marlow, G.C. and W.H. Loescher. 1984. Watercore. Hort. Rev. 6:189251.

McGuire, R.G. 1992. Reporting of objective color measurements. HortScience 27:1254-1255.

Organisation for Economic Co-operation and Development. 1983. International standardisation of fruit and vegetables: Apples and pears (revised). OECD, Paris.

O'Loughlin, G.C. and B.R. Graham. 1993. Loss of late watercore from 'Fuji' apples. Plant Protec. Quart. 8:47-48.

O'Rourke, A.D. 1994. The world apple market. Food Products Press, Binghamton, N.Y.

Watkins, C.B., P.L Brookfield, and F.R. Harker. 1993. Development of maturity indices for the 'Fuji' apple cultivar in relation to watercore incidence. Acta Hort. 326:267-275.

Weibel, E.R. 1979. Stereological methods. vol. 1. Practical methods for biological morphometry. Academic Press, London.

Williams, M.W. 1966. Relationship of sugars and sorbitol to watercore in apples. Proc. Amer. Soc. Hort. Sci. 88:67-75.

Yamada, H., H. Ohmura, C. Arai, and M. Terui. 1994. Effect of preharvest fruit temperature on ripening, sugars, and watercore occurrence in apples. J. Amer. Soc. Hort. Sci. 119:1208-1214. 